\title{
Social work and economic justice in Aotearoa New Zealand
}

\author{
Marissa Kaloga, University of Otago, Aotearoa New Zealand
}

\begin{abstract}
The social work profession is dedicated to the promotion of social and economic justice, but often has a limited appreciation of what economic justice actually looks like either in theory or practice. Economic justice, a form of distributive justice, assesses how fairly economic resources are distributed in a society. Currently, in Aotearoa New Zealand, both income and wealth inequality have reached historically high levels. Inequality research has demonstrated a causal link between inequality and a host of social and health issues that, while they impact society as a whole, affect the nation's most marginalised populations to an increasingly greater degree. Social work literature in Aotearoa New Zealand has limited research in this area. This introductory article will begin with an overview of concepts related to economic justice, such as distributive justice, income inequality, and wealth inequality. Following this is an overview of the 2020 Economic Justice Online Forum and an exploration of the implications for social work.
\end{abstract}

Keywords: Economic justice; Aotearoa New Zealand; social work; inequality

\section{Introduction}

This article is intended as an overview for social workers on the concepts, history, and current opportunities for advancement of economic justice in Aotearoa New Zealand. The text is organised into three sections. The first section provides an overview of key concepts in economic justice, including distributive justice, income inequality, and wealth inequality. In the second section, I present the proceedings of the multidisciplinary Economic Justice Forum held in 2020, which aimed to establish a research agenda for social work and economic justice. The third and final section includes a discussion and call to action for social workers.

\section{What is economic justice?}

The promotion of social and economic justice is core characteristic of social work's mandate as a profession, and differentiates it from other professional areas such as psychology or counseling. This is written into the values and core competencies of social workers in Aotearoa, as "Competence to promote the principles of human rights and social and economic justice" (Social Workers Registration Board [SWRB], 2021). It is also described internationally through the International Federation of Social Work (IFSW) stating that "Social, Economic and Environmental Justice are fundamental pillars underpinning social work theory, policy and practice" (IFSW, 2020). In recent years, the idea of "social" justice has been further disseminated into popular knowledge along with terms like "structural racism" and "implicit bias" increasingly becoming part of the public lexicon. However, the notion of "economic" justice is, for many social workers, merely an addendum to a phrase, lacking an operationalised definition or practical application (Simmons, 2017). Nevertheless,
AOTEAROA

NEW ZEALAND SOCIAL WORK 33(4), 5-13.

CORRESPONDENCE TO: Marissa Kaloga marissa.kaloga@otago.ac.nz 
social and economic justice are intricately tied, and the pursuit of one is inherently linked to the other. In Poverty and Famines: An Essay in Entitlements, Sen (1983) famously pointed out that famines are not by and large caused by an absolute lack of food, but instead because marginalised people in poverty do not have an entitlement to the food that exists. Social and economic justice are likewise connected in major social work practice areas in Aotearoa New Zealand such as child abuse and family harm which have been found to be linked to poverty (Drake \& Jonson-Reid, 2014; Fahmy et al., 2016). Thus, while poverty finds an expression downstream in social inequalities, its causes are often found upstream in unequal resource allocation. Without a thorough understanding of how economic, material realities are tied to social injustice, social workers can struggle to be effective in supporting wellbeing and sustainable solutions for the most marginalised people.

\section{Distributive justice}

One can best understand economic justice through the lens of "distributive justice," which is primarily concerned with how resources are allocated within society. This can apply to basic resources such as housing, food, and livelihoods, but it can also apply to less commodifiable shared societal resources like clear air, education, and opportunities. John Rawls' 1971 book, A Theory of Justice (revised in 1999) provided a widely employed framework for understanding justice, which he defined as fairness under a social contract arrangement in society. In order to implement fairness and attain justice in a society, he outlines three necessary principles, namely the Greatest Equal Liberty Principle, "Each person is to have an equal right to the most extensive total system of equal basic liberties compatible with a similar system of liberty for all" (p. 266); the Difference Principle, "Social and economic inequalities are to be arranged so that they are (a) to the greatest benefit of the least advantaged members of society" consistent with generational equity (p.266); and the Equal Opportunity Principle, "Social and economic inequalities are to be arranged so that they are (b) attached to offices and positions open to all under conditions of fair equality of opportunity" (p. 266). Rawls argued that justice could be ensured by following these principles.

While his work continues to serve as an influential model of justice, Amartya Sen's book, The Idea of Justice (2009) critiques and elaborates upon Rawls' work. In particular, Sen focuses on Rawls' notion of a single, transcendental view of hypothetical justice. Rather than looking for a single idea of justice, Sen's post-modern argument advocates for a plurality of "right" approaches (Brown, 2010), understanding that different claims to justice may have equal weight. Sen's pluralist approach is particularly important in considering distributive justice in the context of competing claims within a bicultural society like Aotearoa New Zealand. There is a tension here-much European influenced thinking draws heavily from an Enlightenment-based tradition where a "best" solution or approach is desired, whereas an Indigenous approach more closely resembles Sen's post-modern argument that allows for different approaches that have equal validity. Justice, as understood by these two groups, may look different and continuously needs to be renegotiated. Victory or even homeostasis may not be the desired outcome but rather a dynamic, active and respectful relationship.

\section{Income and wealth inequality}

Economic Justice is a specific kind of distributive justice focused on people's access to economic resources and their ability to use them as part of their own self-determination. Economic justice is concerned with money and wealth; the ability and opportunity to get money, use it, and save it are crucial to engaging fully in the 21st century world. The unequal opportunity to do these things can result in economic injustice, routinely 
measured as income and wealth inequality. The terms "income inequality" and "wealth inequality" are related, but distinct. Income is paid wages and net profits and does not include assets like houses, or liabilities like consumer debt. Income inequality refers to the difference between earned wages across all deciles, specifically looking at the ratio between the top and the bottom of the income spectrum. In his book, Wealth and New Zealand, Rashbrooke (2015) refers to the great divergence, a marked trend in everwidening income inequality over thirty years in Aotearoa New Zealand, from the 1990s until the 2010s. Inequality in Aotearoa New Zealand began to widen after the neoliberal policies of the 1984-1990 Labour Government and reached their current high levels in the 2010s (Rashbrooke, 2015). This broadening inequality has resulted in the poorest kiwis seeing stagnant wages for more than three decades while the richest doubled their wages in that same timeframe (Rashbrooke, 2015). The impacts of high income inequality like that seen in Aotearoa New Zealand can impact multiple generations, and lead to an intergenerational reduction in social mobility (Corak, 2013). These effects are also relevant when looking at wealth inequality. Wealth consists of a person or household's assets like real estate and investments, minus liabilities like a mortgage or credit card debt. Wealth inequality is a measure used to look at the differences in levels of wealth across the population, which provides important information about how the country's resources are distributed. In Aotearoa New Zealand, while the top decile earns $27 \%$ of all after-tax income, the top decile of asset holders hold 59\% of all wealth (Rashbrooke et al., 2021). This is in stark contrast to the bottom half of the population who own only 5\% of the nation's overall wealth (Rashbrooke, 2015). This concentration of wealth at the top continues to increase and creates an increasingly unequal society that limits opportunity and mobility.

This widening inequality can be seen in a well-recognised form of wealth: owning a home. Rates of homeownership have fallen steadily since their high point in 1991 and are now the lowest they have been in 70 years. In a 2020 report on housing, Statistics New Zealand (StatsNZ) cited a $64.5 \%$ rate of homeownership (StatsNZ, 2020). This has followed a nationwide trend where fewer people are able to buy a home. For people in their prime working years, their late 30 s, rates of home ownership fell $20 \%$ from 1991 (79\%) to 2018 (59\%). Homeownership rates are even lower for Māori $\left(28.2 \%^{1}\right)$ and Pasifika (18.5\%) families (Goodyear, 2017). The drop in overall rates of homeownership coincides with an increase in the concentration of homes owned by investors. In January 2021, for example, 30\% of all homes available were bought by investors rather than families (Leahy, 2021).

\section{Inequality and wellbeing}

The idea of fairness, or justice, in income and wealth is not just a moral imperative; it is also intricately tied to our wellbeing as individuals and a society. In their book, The Spirit Level, Pickett and Wilkinson (2010) present a compelling argument about the relationship between inequality and health where higher levels of inequality negatively impact the health and wellbeing of all people in a society. Since that time, a compelling body of evidence has been created by researchers in multiple disciplines to support this causal link confirming that income and wealth inequality are detrimental to health and wellbeing outcomes population-wide, not just in vulnerable or marginalized groups (Atkinson, 2016; Pickett \& Wilkinson, 2015; Stiglitz, 2015). Inequality causes populationwide disparities, including: shorter life expectancy, higher infant mortality, higher rates of obesity, HIV infection prevalence, increased property crime, increased rates of violence, increased teen pregnancy, decrease in women's equality, decrease in child well-being, increase in school dropout rates, increases in mental illnesses such as depression and suicide, and a decrease in social capital and social cohesion (Wilkinson \& Pickett, 2017). With such a 
widespread evidence base of the negative effects of income and wealth inequality, it is imperative that social workers have a working understanding of these terms and their application in Aotearoa New Zealand. For example, the falling rates of homeownership and concentration of property in the upper wealth deciles has downstream impacts on myriad health and wellbeing issues that practising social workers see on a daily basis. While these effects are often blamed on individual choices, this body of research strongly illustrates their relationships to structural inequities.

\section{New Zealand and the egalitarian ideal}

These widening inequalities and concurrent social issues are at odds with Aotearoa New Zealand's longstanding commitment to the ideal of egalitarianism. Historically, Aotearoa New Zealand has held egalitarianism as an "aspirational ideal" (Easton, 2015). Just as the US falls short of its values of freedom and justice for all, kiwis' value for egalitarianism has been an unevenly applied project with inequity in opportunities for women, people with disabilities, migrants, and indigenous people (Easton, 2020). However, the value still holds strong and acted as a guiding principle for much of Aotearoa New Zealand's modern history. In recent times there has been a growing recognition that, while some sectors of Aotearoa New Zealand society have been doing well, others have not, shown by indicators such as high levels of child poverty that were a major platform of the 2017 coalition government and translated into the Child Poverty Reduction Act (2018). The struggle for economic justice has led to the emergence of forums such as the Child Poverty Action Group, the Equality Network, and a series of discussions prompted by Max Rashbrooke's (2013) book, Inequality: A New Zealand Crisis. The increasing attention to inequality in the public sphere has not been met with equal attention within social work practice or research in Aotearoa. As front-line witnesses to the impacts of inequality on our most vulnerable populations, and with our strongly held values in the promotion of social and economic justice, it is imperative that social workers are active contributors to this national conversation.

\section{Online forum economic justice}

Associate Professor Anaru Eketone and Dr Marissa Kaloga are social work academics with practice experience in promoting economic justice. We had both concluded that social work's lack of attention to economic justice was not reflective of the importance of economic issues for the families we worked with and wanted to explore what a kiwi-specific focus on it might look like. In 2020, with support from Te Puni Kokiri, we co-hosted an online "Economic Justice" forum with the following objectives: 1 . To identify gaps or areas for future inquiry in the application of economic justice in Aotearoa and 2. To establish connections between interested parties, which will form the basis of a research and action network organised around principles of economic justice. During this forum, speakers from varied disciplines shared brief presentations of their research and/or practice work. Speakers included (in order): Dr Marissa Kaloga, Mr Trevor McGlinchy, Dr Diane Ruwhiu, Ms Rasha Abu Safieh, Professor Stephen Knowles, Dr Pushpa Wood, Ms Lisa Lopeti, and Dr Anaru Eketone. Following the speakers, small group and open discussion centred on what was driving disparities, how to learn from one another, intergenerational thinking, reframing the concept of "beneficiary" to contributor, decolonising wealth, and learning from what is already working (see Figure 1).

Following the forum, the authors reviewed detailed notes taken during the event, and identified several emergent thematic areas, namely: 1 . setting a new direction with ambitious goals; 2 . Aotearoa's specific context and diverse economies; 3 . the need for correct information on issues of 
Figure 1 Economic Justice Forum Conversation Topics

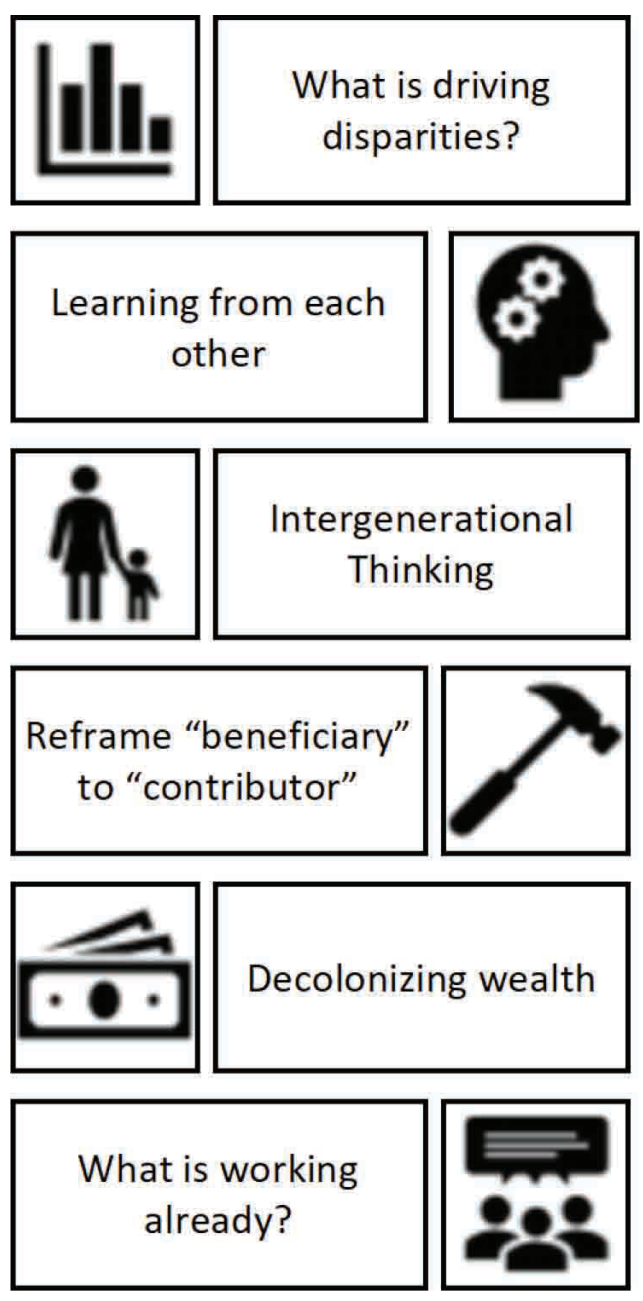

economic justice; 4. making connections between diverse stakeholder groups; 5 . the need to address urgent needs; and 6. the role of hope in economic justice. These six themes comprise a first attempt at exploring a social work agenda for economic justice in Aotearoa, New Zealand that draws from multidisciplinary thinking on the topic.

\section{Setting a new direction with ambitious goals}

The participants at the forum recognised that social work in Aotearoa was not focused on economic justice as a foundational area of practice. That, combined with the current severe state of inequality in the country, led participants to support setting ambitious goals. They reasoned that a larger vision would encourage transformational ideas rather than supporting status quo with bandaid solutions. National economic policies like the Wellbeing Budget (Keck, 2021), increases in minimum wage (McClure, 2021), and transition to a sustainable financial system (BBC, 2021) are gaining global recognition for being progressive and innovative. Social work in Aotearoa must also set innovative and progressive goals for economic justice to ensure that the most vulnerable among us are not left behind as these and other policies are implemented.

\section{Aotearoa New Zealand's specific context and diverse economies}

While social work academics and practitioners outside of Aotearoa New Zealand have generated impactful research on economic justice (Center for Social Development (CSD), 2021; Grand Challenges for Social Work (GCSW), 2021), the implications and recommendations from this work do not consider the unique context of Aotearoa New Zealand. The bi-cultural society, small population, geographic isolation, and export economy make Aotearoa New Zealand's economy unique among other Global North countries. Participants related that, while existing literature and practices in this space can inform social work's response to issues of economic justice, our unique context requires that our responses are generated and validated locally.

\section{The need for correct information on issues of economic justice}

Because of the need for unique solutions, it is crucial that social workers have access to information that can inform their research and practice. Multiple participants voiced a concern that there are areas of economic justice where social workers do not have sufficient data, either quantitative or qualitative, to have a holistic understanding 
of economic justice issues. With this data, plans can be made to prioritise key indicators and to identify any success such as with the government's child poverty objectives in the Child Poverty Reduction Act (2018).

\section{Making connections between diverse stakeholder groups}

The speakers at the forum had expertise in diverse sectors, including social work, economics, management, social enterprise, refugee services, and non-profit leadership. Multiple participants noted that the interdisciplinary nature of the forum challenged them to look at similar issues from different perspectives and learn from one another's experience and knowledge. The issues of economic justice are complex, and as such finding realistic solutions will likely require significant inter-sectoral collaboration.

Participants observed that, while there were gaps in research within their own discipline or sector, it was possible that useful data were available in other disciplines or sectors. Thus, the lack of information and data on issues of economic justice noted above might be somewhat mitigated by collaboration and information-sharing.

\section{The need to address urgent needs}

Some participants discussed macro-level and policy interventions to support economic justice, but others supported addressing families' urgent economic needs now. The interplay between micro and macro social work practice was evident in the discussion, where the need to advocate and create positive systems and structural change in the future did not diminish social work's obligation to address individual suffering in the present. Participants agreed that a "both/ and" solution was necessary, where micro and macro social work practitioners worked collaboratively to understand the historical roots of economic injustice, address issues of injustice in the present, and promote better solutions for the future.

\section{The role of hope in economic justice}

The role of hope was brought up by a practitioner working on issues of economic inequality. Hope, the desire and expectation of a better world, is what inspires practitioners across disciplines. Social work has to be more than assisting people to be comfortable in their oppression and grateful in their poverty. Social change is as linked to social justice as economic change is to economic justice.

In order to begin delivering on this agenda and fulfil the objectives of the Economic Justice Online Forum, Associate Professor Eketone and Dr Kaloga are co-editing this

Figure 2 Six Thematic Areas from Economic Justice Forum 2020

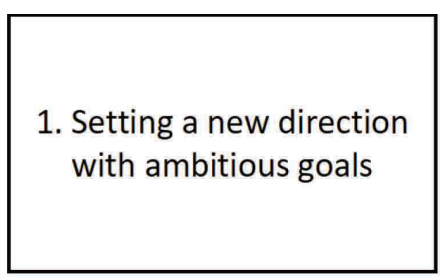

4. Connections between: researchers, communities, policy makers, Do'ers, economic institutions, private business

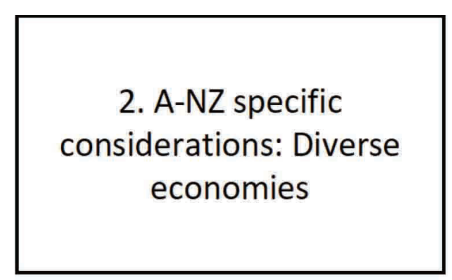

5. Both/And - Address dire needs of population AND set a path for a more economically just future

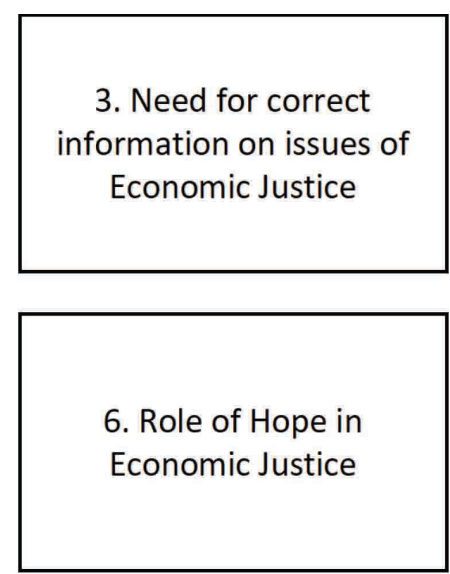


section on economic justice for publication in the Aotearoa New Zealand Social Work journal.

\section{Social work implications}

Fulcher (1994) borrowed a familiar idiom to describe the Aotearoa New Zealand health sector reform: "When you're up to your neck in alligators, it's hard to remember the original aim was to drain the swamp." This phrase can equally be applied to the social work profession, where the immediacy and omnipresence of individuals' and families' needs can distract from the necessity to advance justice through structural and system changes. The alligator metaphor can be also applied to social workers' engagement with issues of economic justice. On a micro level, social workers constantly engage with issues of economic poverty as they work with people to secure employment, food, or housing. However, these issues are the consequences of larger systemic issues of economic inequality. With the front-line knowledge they generate through their work, it is thus imperative that social workers have an understanding of those structural drivers and advocate for just policies and actions when appropriate, as their practice-wisdom provides a valuable perspective in these conversations. In addition, the applied systemic approach unique to this profession suggests that social work can have a strong convening presence on the complex issues of economic injustice. As described in the themes from the Economic Justice Forum, there is a need for strong datasets to inform our thinking, but some data are not available. This is particularly critical in the unique context of Aotearoa New Zealand, as answers generated in other nations-while they can inform our thinking-will likely not be sufficient to create solutions to our distinct needs, or use methods that adhere to our values and Treaty obligations. One way to address the lack of data is through interdisciplinary collaboration, which provides the opportunity to learn from others' data and analysis using diverse perspectives. Social workers' pragmatism centres our focus on supporting positive change in peoples' lives, not on maintaining territory or authority, and this stance allows us to act as good-faith relationship builders across professional boundaries and topical research areas.

\section{Conclusion}

Ultimately, the struggle against economic injustice is not new. It has come to the fore at numerous times throughout the history of Aotearoa New Zealand and feeds into the New Zealand psyche that has traditionally upheld equality and egalitarianism as a dominant theme in the identity of the nation. However, due to the unprecedented spike in economic inequality, both income and wealth inequality have reached historically high levels and the current situation is untenable. Economic injustice causes hardship not only for people in poverty, but more broadly it is linked to dozens of health issues across the entire population (Wilkinson \& Pickett, 2017), including increases in family violence and mental illness. Therefore, social workers cannot claim to promote social justice if we continue to ignore the impact economic injustice is having on the very families and communities we work to support.

The Economic Justice Forum was a first step in bringing social work into the larger research and policy conversations on these issues. During this event, participants developed ideas about how to best address economic injustice in Aotearoa New Zealand including setting ambitious goals, the need for good research and data, utilising networks, and the role of hope in Aotearoa's unique political and cultural environment. Interdisciplinary collaboration is necessary to address the economic injustices currently faced. Social work has an important role to play in the struggle for economic justice, but the profession is neither applying its full practice wisdom and convening power nor developing new knowledge in economics necessary for effectively advocating for people in poverty. 
Bold solutions are necessary, and while social work can be a strong driving force behind the work, it cannot act alone. As a profession of action, we cannot only wrestle with the "alligators" alongside families in poverty without being equally attentive to the "swamp" of income and wealth inequality. Social work's perspective is critical in developing solutions that are systemic, interdisciplinary, pragmatic, responsive to the needs of marginalised people, and protective of the inherent dignity and human rights of each individual. The history of economic justice work has already been written. The present state of economic injustice is unsustainable. The Economic Justice Forum provided a platform for social work to engage with interdisciplinary knowledge in this area, and to create a set of opportunities for action. The future of social work's role in advocating for economic justice will be written through the actions of social work academics and practitioners who engage in this space.

\section{Notes}

1 In her paper, Goodyear adjusts the homeownership rate for age of population, and suggests 35\% for Maori and $24.4 \%$ for Pacifica. These numbers are still below general homeownership figures, and are shown to be declining.

ORCid: 0000-0001-5897-6952

Accepted 28 November 2021

Published 23 December 2021

\section{References}

Atkinson, A. B. (2016). Inequality: What can be done. Practice, 4O(2), 289-292.

BBC. (2021). NZ to launch world-first climate change rules. BBC News. https://www.bbc.com/news/ business- 56728381

Brown, C. (2010). On Amartya Sen and the idea of justice. Ethics \& International Affairs, 24(3), 309-318.

Corak, M. (2013). Income inequality, equality of opportunity, and intergenerational mobility. Journal of Economic Perspectives, 27(3), 79-102.

Center for Social Development (CSD). (2021). Financial inclusion. Washington University of St Louis. https://csd. wustl.edu/areas-of-work/financial-inclusion/
Drake, B., \& Jonson-Reid, M. (2014). Poverty and child maltreatment. In J. E. Korbin \& R. D. Krugman (eds), Handbook of child maltreatment (pp. 131-148). Springer.

Easton, B. H. (2015). An egalitarian society? Briefing papers. http://briefingpapers.co.nz/an-egalitarian-society/

Easton, B. H. (2020). Not in narrow seas: The economic history of Aotearoa New Zealand. Victoria University of Wellington Press.

Fahmy, E., Williamson, E., \& Pantazis, C. (2016). Evidence and policy review: Domestic violence and poverty. Joseph Rowntree Foundation.

Fulcher, L. C. (1994). When you're up to your neck in alligators, it's hard to remember that the original aim was to drain the swamp: Some lessons from New Zealand health sector reform. Australian Social Work, 47(2), 47-53.

Grand Challenges for Social Work (GCSW). (2021). Reduce extreme economic inequality. https:// grandchallengesforsocialwork.org/reduce-extremeeconomic-inequality/

Goodyear, R. (2017). A place to call home? Declining homeownership rates for Māori and Pacific peoples in New Zealand. New Zealand Population Review, 43, 3-34.

International Federation of Social Workers (IFSW). (2020). Global standards for social work education and training https://www.ifsw.org/global-standards-for-social-workeducation-and-training/

Keck, M. (2021). New Zealand's “Wellbeing" budget tackles climate change, inequality and regional COVID-19 recovery. https://www.globalcitizen.org/en/content/newzealand-wellbeing-budget/

Leahy, B. (2021, February 17). Investors buy record share of homes as first-home buyers squeezed. NZ Herald. https://www.nzherald.co.nz/business/investors-buyrecord-share-of-homes-as-first-home-buyers-squeezed/ V3P57LU2XJLY2YB4RDUYYZ27NU/

McClure, T. (2021, March 31, 2021). New Zealand raises minimum wage and increases taxes on the rich. The Guardian. https://www.theguardian.com/world/2021/ mar/31/new-zealand-raises-minimum-wage-andincreases-taxes-on-the-rich

Pickett, K., \& Wilkinson, R. (2010). The spirit level: Why equality is better for everyone: Penguin UK.

Pickett, K. E., \& Wilkinson, R. G. (2015). Income inequality and health: a causal review. Social Science \& Medicine, 128, 316-326.

Rashbrooke, M. (2013). Inequality: A New Zealand crisis: Bridget Williams Books.

Rashbrooke, M. (2015). Wealth and New Zealand (Vol. 34): Bridget Williams Books.

Rashbrooke, M., Geoff, R., \& Chin, A. (2021). Wealth inequality in New Zealand: An analysis of the 2014-15 and 2017-18 net worth modules in the Household Economic Survey. https://www.wgtn. ac.nz/_data/assets/pdf_file/0007/1935430/WP-21-10wealthinequality-in-New-Zealand.pdf

Rawls, J. (1999). A theory of justice (Rev. ed.). Harvard University Press. (Original work published 1971)

Sen, A. K. (1983). Poverty and famines: An essay on entitlements and deprivation. Oxford University Press

Sen, A. K. (2009). The idea of justice: Harvard University Press. 
Simmons, L. (2017). Economic justice. In Encyclopedia of Social Work. National Association of Social Workers Press and Oxford University Press. https://doi. org/10.1093/acrefore/9780199975839.013.1266

Statistics New Zealand (StatsNZ). (2020). Housing in Aotearoa: 2020. https://www.stats.govt.nz/assets/ Uploads/Reports/Housing-in-Aotearoa-2020/Downloaddata/housing-in-aotearoa-2020.pdf

Stiglitz, J. E. (2015). The price of inequality: How today's divided society endangers our future.

Social Workers Registration Board (SWRB). (2021). Ngā Paerewa Kaiakatanga Matua core competence standards. https://swrb.govt.nz/practice/corecompetence-standards/Author.

Wilkinson, R. G., \& Pickett, K. E. (2017). The enemy between us: The psychological and social costs of inequality. European Journal of Social Psychology, 47(1), 11-24. 